\title{
A regional ocean-atmosphere coupled model developed for CORDEX East Asia: assessment of Asian summer monsoon simulation
}

\author{
Liwei Zou $^{1} \cdot$ Tianjun Zhou ${ }^{1}$
}

Received: 12 August 2015 / Accepted: 10 February 2016 / Published online: 26 February 2016

(C) The Author(s) 2016. This article is published with open access at Springerlink.com

\begin{abstract}
In this study, a developed regional oceanatmosphere coupled model FROALS was applied to the CORDEX East Asia domain. The performance of FROALS in the simulation of Asian summer monsoon during 19892010 was assessed using the metrics developed by the CLIVAR Asian-Australian Monsoon Panel Diagnostics Task Team. The results indicated that FROALS exhibited good performance in simulating Asian summer monsoon climatology. The simulated JJA mean SST biases were weaker than those of the CMIP5 multi-model ensemble mean (MMEM). The skill of FROALS approached that of CMIP5 MMEM in terms of the annual cycle of Asian summer monsoon. The simulated monsoon duration matched the observed counterpart well (with a spatial pattern correlation coefficient of 0.59). Some biases of CMIP5 MMEM were also found in FROALS, highlighting the importance of local forcing and model physics within the Asian monsoon domain. Corresponding to a strong East Asian summer monsoon, an anomalous anticyclone was found over western North Pacific in both observation and simulation. However, the simulated strength was weaker than the observed due to the responses to incorrect sea surface anomalies over the key regions. The model also accurately captured the spatial pattern of the intraseasonal variability variance and the extreme climate indices of Asian summer monsoons, although with larger amplitude. The results suggest that FROALS could be used as a dynamical downscaling tool nested within the global climate model with coarse
\end{abstract}

Liwei Zou

zoulw@mail.iap.ac.cn

1 LASG, Institute of Atmospheric Physics, Chinese Academy of Sciences, Beijing 100029, China resolution to develop high-resolution regional climate change projections over the CORDEX East Asia domain.

Keywords Regional climate modeling - Asian summer monsoon $\cdot$ CORDEX $\cdot$ Regional air-sea coupling

\section{Introduction}

Asian monsoon influences countries with more than one third of the world's population. Thus, predictions of Asian monsoon at various timescales are of great interest to governmental decision-makers. Climate models have been widely used as a tool for understanding and forecasting the variation of Asian monsoon. In prescribed sea surface temperature experiments, Zhou et al. (2009a) analyzed the output of atmospheric general circulation models (AGCMs) that participated in the climate variability and predictability (CLIVAR) international climate of the twentieth century (C20C) project and found that among the Asian-Australian monsoon subsystems the East Asian summer monsoon has the lowest reproducibility and is poorly modeled during 1950-1999. Song and Zhou (2014a) compared the climatology and interannual variability of East Asian summer monsoon simulated by CMIP3 (coupled model intercomparison project phase 3) and CMIP5 AGCMs. The results indicated that some improvements were seen from CMIP3 multi-model ensemble mean (MMEM) to CMIP5 MMEM, but the simulated biases remained, i.e., northward shift of the western North Pacific subtropical high. For the atmosphere-ocean-land coupled simulations, Sperber et al. (2013) compared the simulated Asian summer monsoon by the coupled models from CMIP3 and CMIP5, and found that the CMIP5 MMEM was more skillful than the CMIP3 MMEM in terms of pattern correlations. However, large 
intermodel spread existed (Huang et al. 2013; Chen and Bordoni 2014).

The modeling of Asian summer monsoon remains a grand challenge for climate models due to its nature of variety and complexity (Turner et al. 2011). The studies of the past 10 years suggested that one way to improve the simulation of the Asian summer monsoon is the development of a coupled ocean atmosphere model. In prescribed SST experiments, the simulated rainfall is positively correlated with local SST over Asian monsoon region instead of negative relationship in nature (Wang et al. 2004a, 2005). Therefore, the lack of air-sea interaction has been regarded as the major factor contributing to the poor simulated rainfall over the Asian summer monsoon region in SST forced simulations (Zhou et al. 2009a, b; Li et al. 2010). Another possible way to improve the simulation of the Asian summer monsoon is to develop high-resolution climate models. Higher resolution may better resolve many monsoon features including orographic forced rainfall, low-level jet orientation and variability, as well as the Meiyu onset and withdrawal (Kusunoki et al. 2006; Kitoh and Kusunoki 2008).

High resolution globally is computationally expensive, however, over limited regions, it is computationally acceptable. Regional climate models (RCMs) have been widely used as a useful tool for regional climate studies (Giorgi and Mearns 1999; Leung et al. 2003; Wang et al. 2004b; Christensen et al. 2007). In the past 10 years, many regional ocean atmosphere coupled models have been developed with focus on the South China Sea monsoon ( $\mathrm{Lu}$ et al. 2000), the East Asian monsoon (Ren and Qian 2005; Yao and Zhang 2010; Li and Zhou 2010; Fang et al. 2010; Cha et al. 2016), the Indian monsoon (Ratnam et al. 2009), and the western North Pacific monsoon (Zou and Zhou 2011, 2012, 2013a). However, no model has focused on the entire Asian monsoon. The results indicated that the monsoon circulation and rainfall are better simulated in the regional climate models with inclusion of local air-sea coupling.

The ongoing coordinated regional downscaling experiment (CORDEX) (Giorgi et al. 2009; Jones et al. 2011), whose aim is to develop high-resolution regional climate change projections for all land-regions of the globe by using multi-regional climate downscaling (RCD) methods, has a common setting of a simulated domain for facilitating model inter-comparisons. The CORDEX East Asia domain covers a large portion of the eastern Indian Ocean and the western North Pacific (Fig. 1). However, most of the RCMs that participated in CORDEX East Asia have not taken into account local air-sea interactions (https://cordex-ea.climate.go.kr/main/modelsPage.do).

In this study, the previously developed regional ocean atmosphere coupled model FROALS (Zou and Zhou 2013a) is applied to the CORDEX East Asia domain. FROALS exhibited reasonable performance in the simulation of the western North Pacific summer monsoon in terms of climatology and interannual variability (Zou and Zhou 2013a). However, the model performance over the CORDEX East Asia domain remains unknown. The objective of the study is to evaluate both the strengths and the weakness of the FROALS model in the simulation of the boreal summer Asian monsoon compared to observations. The metrics used to present quantitative assessments of the model's monsoon performance relative

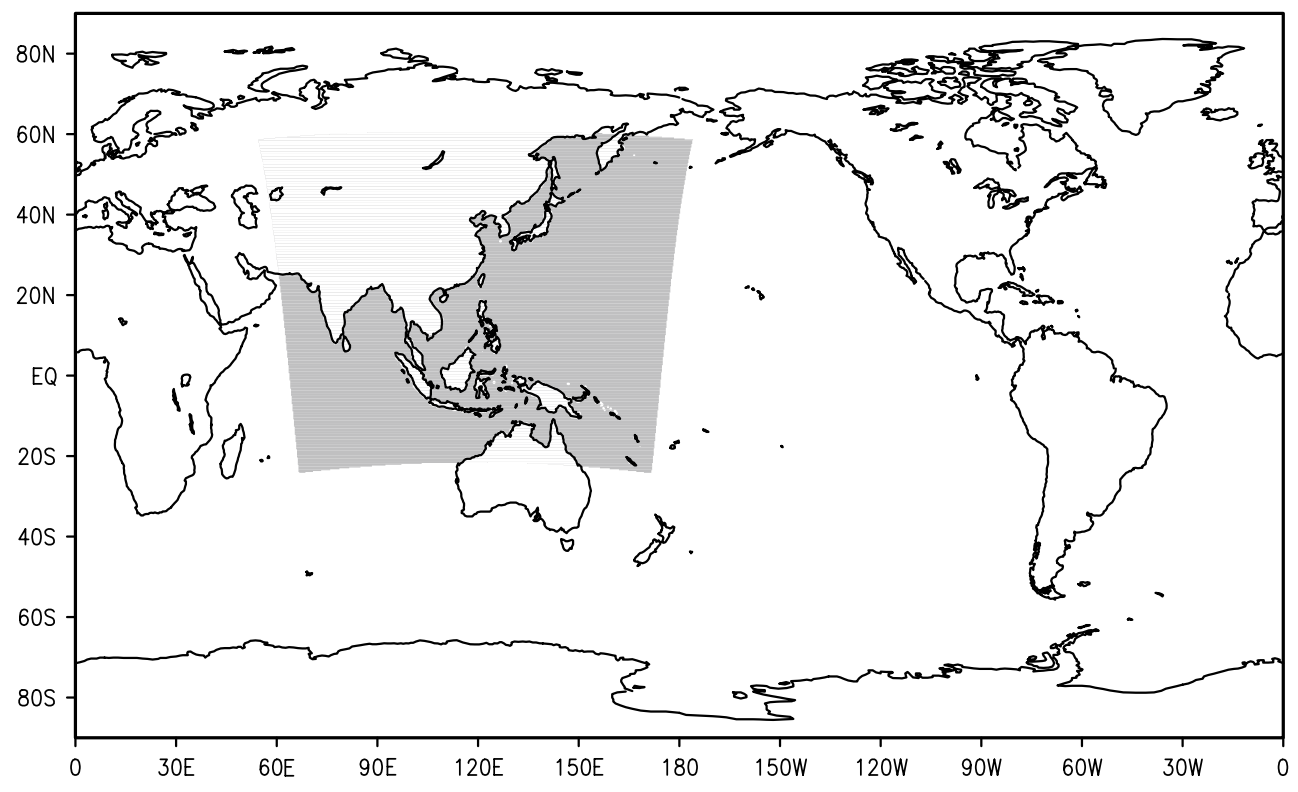

Fig. 1 Configuration of the regional ocean atmosphere coupled model FROALS. The oceanic and atmospheric components are fully interactive over the CORDEX East Asia domain (dashed region), and the ocean model is driven by the NCEP2 in other regions 
to observations were developed by the CLIVAR AsianAustralian Monsoon Panel (AAMP) Diagnostics Task Team and have been used in assessing the CMIP5 global models (Sperber et al. 2013). The metrics cover multiscale characteristics of the Asian monsoon ranging from mean states and intraseasonal variation to interannual variability. We hope to provide a broad overview of the ability of the FROALS model to simulate the Asian summer monsoon based on these metrics. The employment of nearly identical metrics also facilitates our comparison of regional model performance to CMIP5 global models in our analysis.

The rest of the paper is organized as follows. Section 2 describes the model and the experimental design. Summer mean rainfall, sea surface temperature, and $850 \mathrm{hPa}$ winds are evaluated in Sect. 3. Section 4 presents the results on the climatological annual cycle and the timing of monsoon onset, peak, withdrawal, and duration. The interannual variability of the Asian summer monsoon is assessed in Sect. 5 . Section 6 discusses the simulated boreal summer intraseasonal variability, including an analysis of extreme climate indices. A final summary is given in Sect. 7.

\section{Model description and experimental design}

\subsection{Model description}

The flexible regional ocean atmosphere land system model (FROALS) (Zou and Zhou 2013a) is employed in this study, which was developed at the State Key Laboratory of Numerical Modeling for Atmospheric Sciences and Geophysical Fluid Dynamics/Institute of Atmospheric Physics (LASG/IAP). FROALS is coupled through the Ocean Atmosphere Sea Ice Soil 3.0 (OASIS3.0) coupler (Valcke 2006). The regional atmospheric model component of FROALS is the regional model regional climate model version 3 (RegCM3) that was developed at the Abdus Salam International Centre for Theoretical Physics (ICTP) (Pal et al. 2007). It is a hydrostatic, compressible model with terrain following a sigma vertical coordinate system. The selected model physics are as follows: the MIT-Emanuel cumulus parameterization scheme (Emanuel 1991; Emanuel and Rothman 1999), the Subgrid Explicit Moisture Scheme (Pal et al. 2000), the radiation package of the NCAR community climate model version 3 (Kiehl et al. 1996), the non-local vertical diffusion scheme of Holtslag et al. (1990), the biosphere-atmosphere transfer scheme (BATS) of Dickinson et al. (1993), and the ocean-atmosphere flux algorithm proposed by Zeng et al. (1998). Customization of RegCM3 with the MIT-Emanuel cumulus scheme for the CORDEX East Asia domain was completed by Zou et al. (2014) by tuning the selected seven parameters based on the multiple very fast simulated annealing (MVFSA) approach. The identified optimal parameters are adopted in this study.

The oceanic component is the climate system ocean model LICOM2 developed by LASG/IAP (Liu et al. 2012). LICOM2 has been employed as the oceanic component of the LASG/IAP global ocean-atmosphere coupled model FGOALS that participated in CMIP5 (Li et al. 2013; Bao et al. 2013). It adopts the geographic longitude-latitude grid

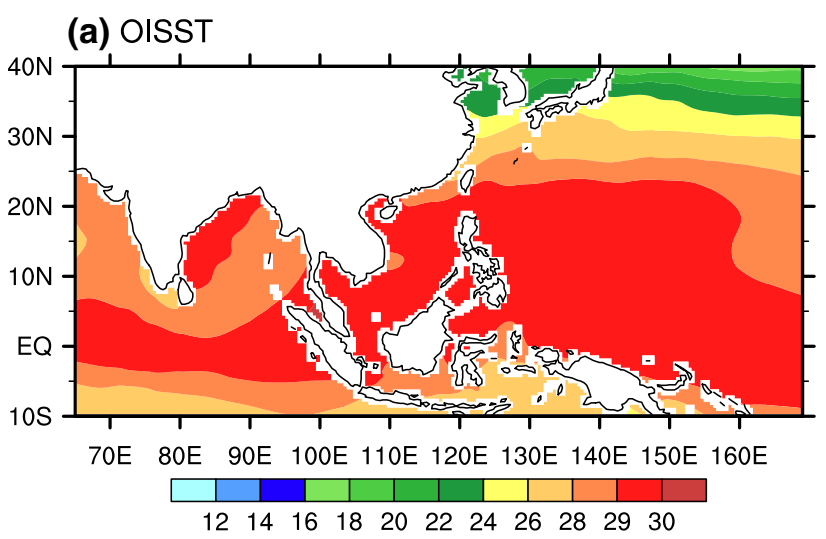

(b) FROALS

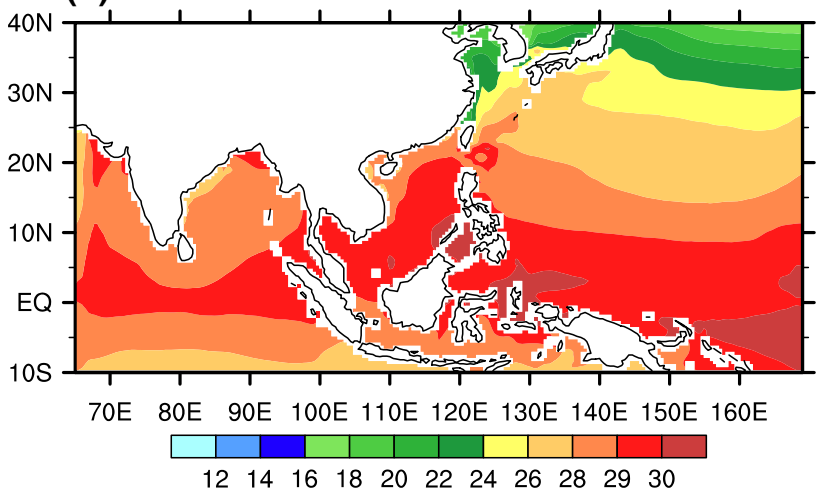

(c) FROALS-OISST

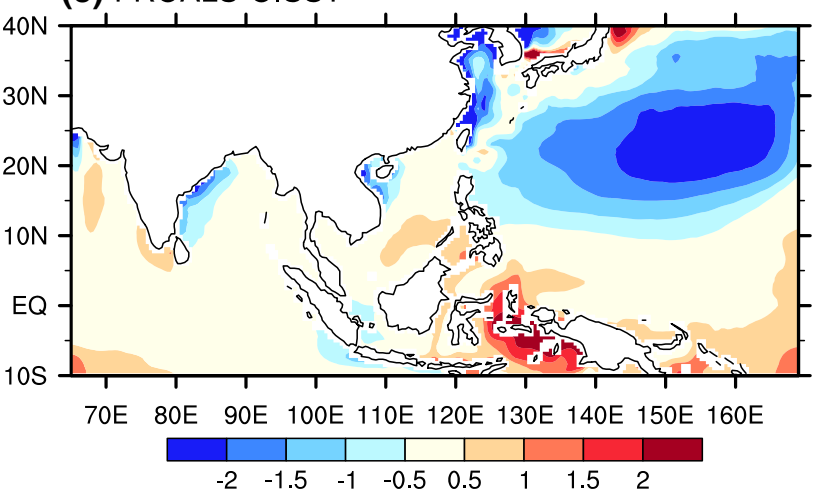

Fig. 2 Spatial distributions of June-July-August mean sea surface temperature (SST, ${ }^{\circ} \mathrm{C}$ ) averaged from 1989 to 2010 from a OISST and $\mathbf{b}$ FROALS. Differences of SST between FROALS and OISST are shown in $\mathbf{c}$ 
(a) GPCP

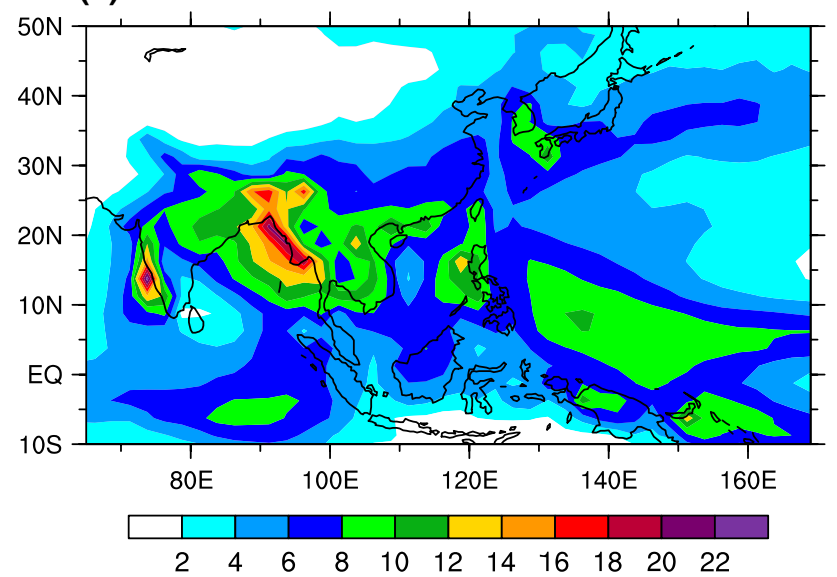

(b) FROALS

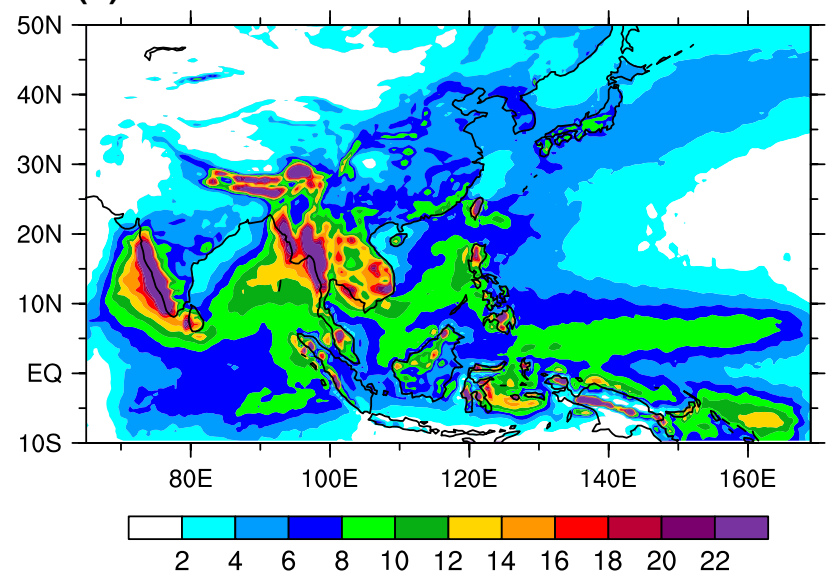

(c) FROALS-GPCP

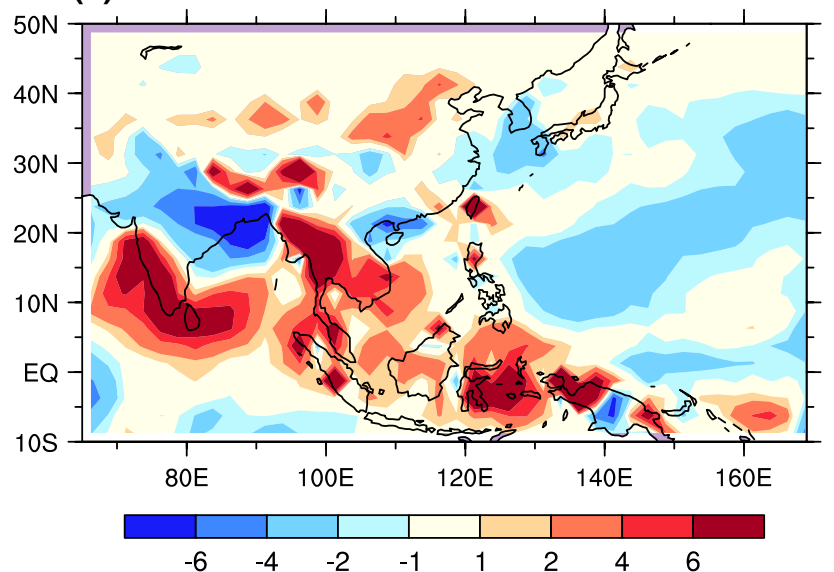

Fig. 3 Spatial distributions of JJA mean rainfall (mm/day) averaged during 1989-2010 from a GPCP and b FROALS. Differences between FROALS and GPCP are shown in $\mathbf{c}$ (a) NCEP2

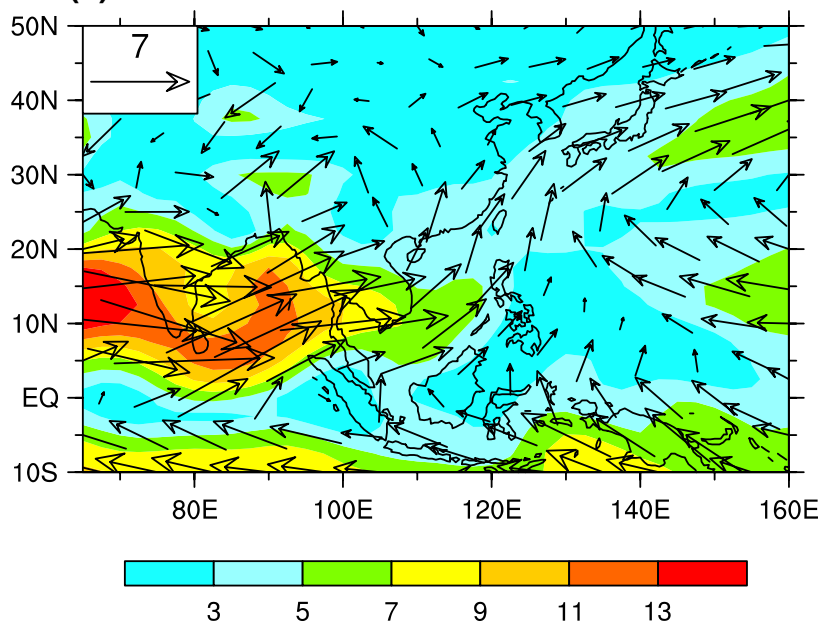

(b) FROALS

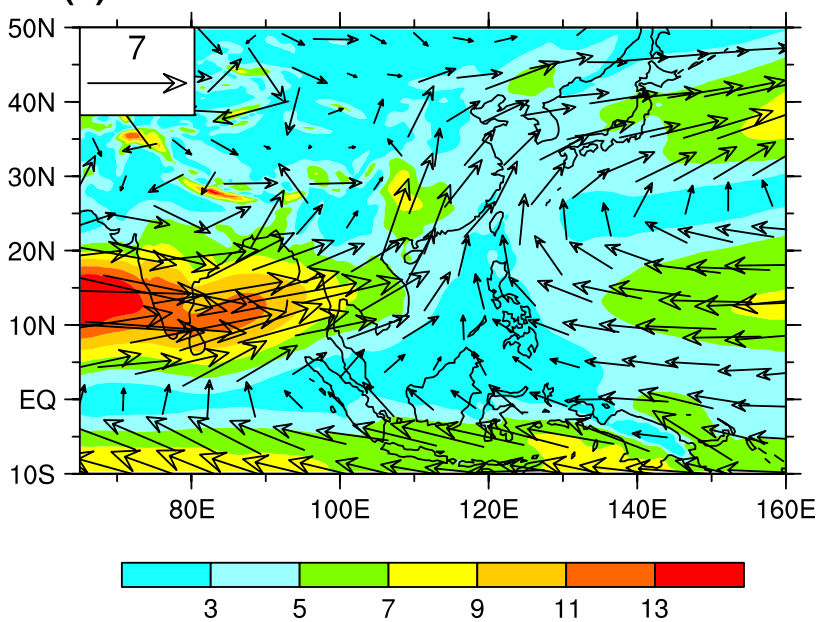

(c) FROALS-NCEP2

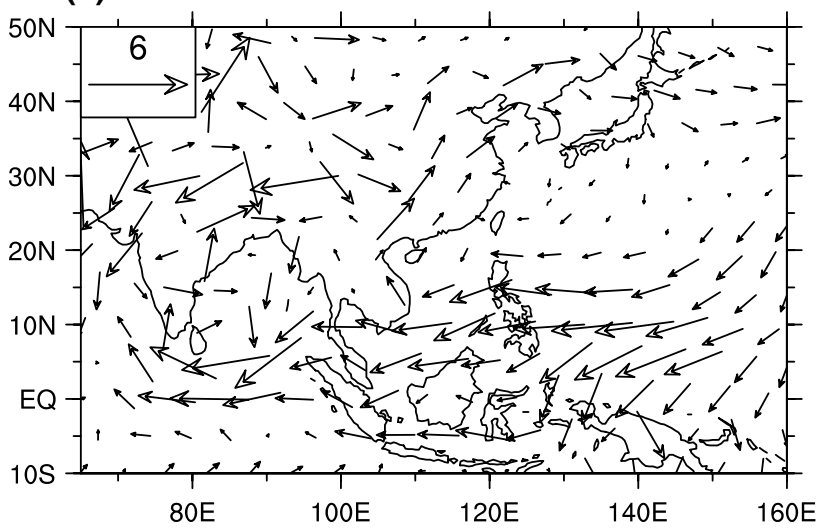

Fig. 4 Spatial distributions of JJA mean $850 \mathrm{hPa}$ low-level wind and associated wind speed $(\mathrm{m} / \mathrm{s})$ derived from a NCEP2, b FROALS, during 1989-2010. Differences between FROALS and NCEP2 are shown in $\mathbf{c}$ 
and coordinates in the vertical. A second order closure turbulence model (Canuto et al. 2001, 2002) is used to parameterize the vertical mixing process due to the velocity shear and the internal-wave break. The GM90 scheme (Gent and McWilliams 1990) is used to parameterize the mesoscale eddy.

\subsection{Experimental design}

The model domain of RegCM3 is set to the CORDEX East Asia domain (Giorgi et al. 2009; Jones et al. 2011) with a uniform horizontal resolution of $50 \mathrm{~km}$. The model has 18 sigma layers in the vertical direction, with the model top at $10 \mathrm{hPa}$. The buffer zone of RegCM3 is 15 grid layers. The initial and lateral boundary conditions are derived from the National Center for Environmental Prediction/Department of Energy (NCEP/DOE) reanalysis 2 (R2) (NCEP2 hereafter) (Kanamitsu et al. 2002), which is updated every $6 \mathrm{~h}$.

LICOM2 is a global climate ocean model that covers $75^{\circ} \mathrm{S}-90^{\circ} \mathrm{N}$. There are 30 vertical levels with 15 equally spaced levels in the upper $150 \mathrm{~m}$. The meridional grid spacing is $0.5^{\circ}$ between $10^{\circ} \mathrm{S}$ and $10^{\circ} \mathrm{N}$ and is then gradually increased to $1^{\circ}$ between $20^{\circ} \mathrm{S}$ and $20^{\circ} \mathrm{N}$, whereas the latitudinal grid spacing is uniformly $1^{\circ}$. Over the oceanic region of the CORDEX East Asia domain (dashed area of Fig. 1), RegCM3 and LICOM2 are fully interactive. RegCM3 provides the sea surface heat flux and wind stress to LICOM, while LICOM supplies the SST field to RegCM3. The coupling of daily mean variables is performed once per day. Outside of the CORDEX East Asia domain, however, the
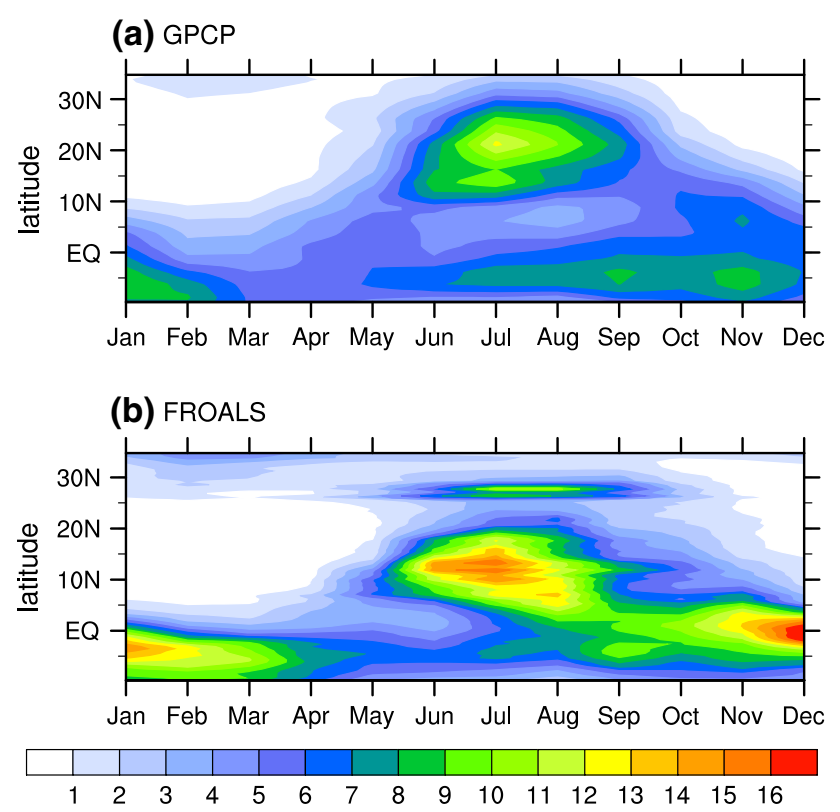

Fig. 5 Annual cycle climatology for rainfall rate ( $\mathrm{mm} /$ day) averaged between $70^{\circ} \mathrm{E}$ and $90^{\circ} \mathrm{E}$ from $\mathbf{a}$ GPCP and b FROALS ocean is forced by the NCEP2 daily mean surface variables. This regionally coupled configuration has also been employed in Aldrian et al. (2005) for the Maritime continent and in Xie et al. (2007) for the eastern Pacific region. In our case, there are some discontinuities of the sea surface temperatures along the boundaries of the regional model. The discontinuities are found inside the buffer zone, which are excluded in the analysis.

The regionally coupled simulation begins from 1 January 1988. Prior to this, LICOM2.0 was forced by the NCEP2 daily surface variables for 9 years, from 1979 through 1987, with an initial condition derived from the World Ocean Atlas 2005 (WOA05) (Locarnini et al. 2006; Antonov et al. 2006) temperature and salinity. The regionally coupled model is integrated 23 years from 1988 through 2010. The first year, 1988 , is regarded as the "spin-up" time of the regionally coupled simulations, and the results are excluded in the following analysis. We have checked the evolution of monthly mean SST averaged over the regionally coupled region during 1988-2010 from the FROALS simulations (figure not shown here). The result indicates that the first model year is a reasonable spin-up time for the regional coupled simulation, since the simulated regional-averaged SST does not show evident drift because of the NCEP2-forcing outside of the regionally coupled domain.

\subsection{Observational datasets}

The following datasets are used to assess the model performance: (1) pentad precipitation data (from 1989 to
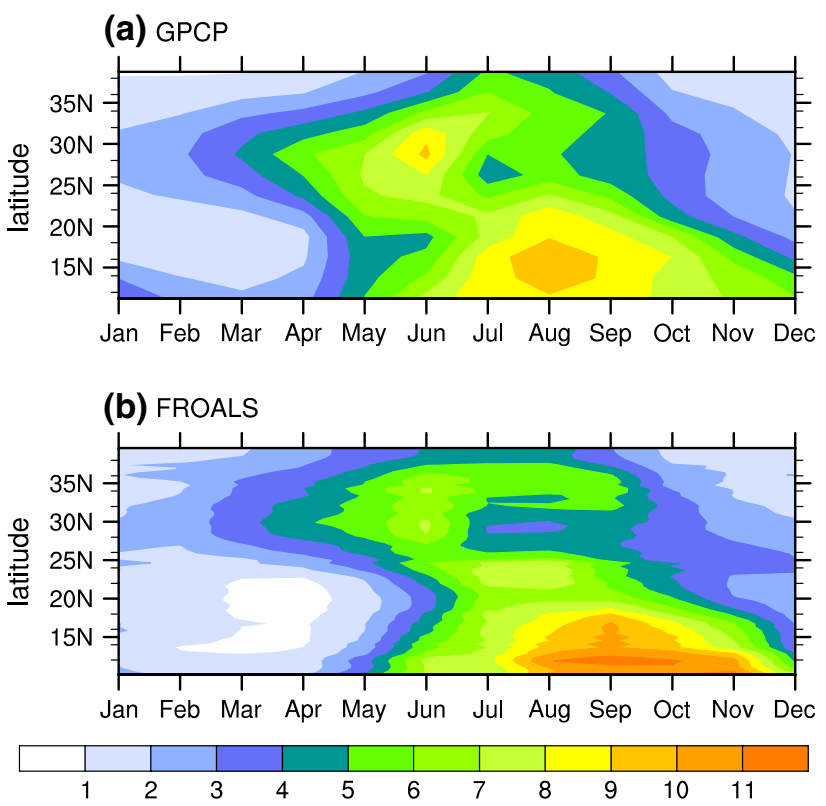

Fig. 6 Annual cycle climatology for rainfall rate (mm/day) averaged between $105^{\circ} \mathrm{E}$ and $140^{\circ} \mathrm{E}$ from $\mathbf{a}$ GPCP and $\mathbf{b}$ FROALS 
Fig. 7 Spatial distributions of Asian summer monsoon onset pentad derived from a GPCP and $\mathbf{b}$ FROALS. Spatial patterns of Asian monsoon peak pentad derived from $\mathbf{c}$ GPCP and $\mathbf{d}$ FROALS. The results are presented with the grid of individual model/observation. Note that pentad 30 is end of May (a) GPCP

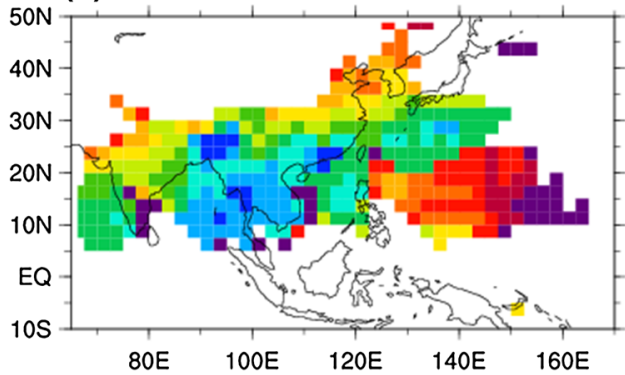

(b) FROALS

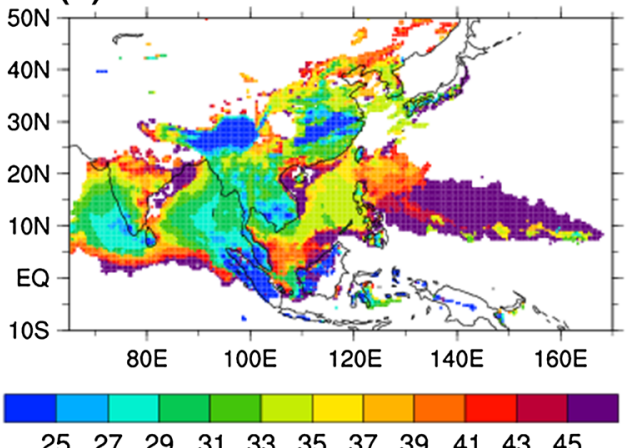

(c) GPCP

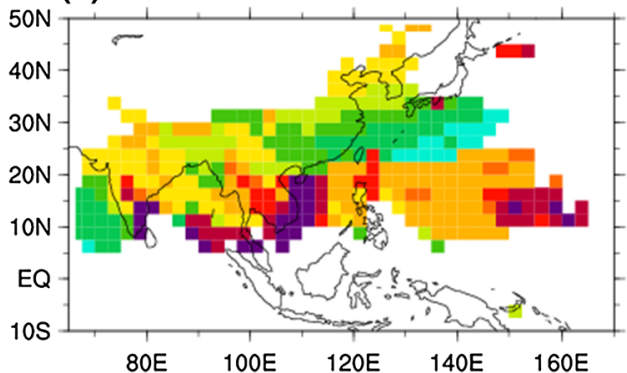

(d) FROALS

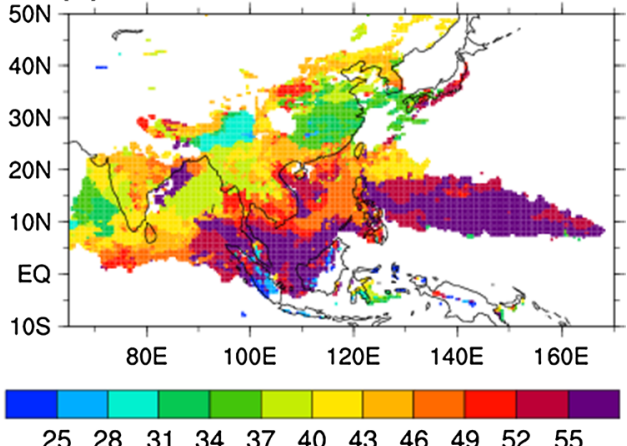

2010) and daily precipitation (from 1998 to 2010) from the Global Precipitation Climatology Project (GPCP; Adler et al. 2003); (2) observational SST derived from the OISST2 dataset (Reynolds et al. 2002); (3) monthly mean circulation field (e.g., u, v, q) derived from NCEP2. For simplicity, the rainfall dataset and the reanalysis-derived circulation dataset are referred to as "observation" in the following discussion.

\section{Time-mean state}

SST is the direct product of air-sea coupling. Figure 2 shows the observed and simulated spatial distribution of June-July-August (JJA) mean SST averaged during 1989-2010. The observed warm pool, where SST exceeds $28{ }^{\circ} \mathrm{C}$, extends to north of $20^{\circ} \mathrm{N}$ (Fig. 2a). The broad observed features of SST are well captured in FROALS, with a spatial pattern correlation coefficient (PCC) of 0.98 . The major deficiency is that FROALS tends to underestimate the SST over the western North Pacific (WNP) north of $10^{\circ} \mathrm{N}$, with the largest bias of approximately $2{ }^{\circ} \mathrm{C}$. The cold biases of the simulated SST over WNP are the common biases in regional ocean-atmosphere coupled models (Ren and Qian 2005; Li and Zhou 2010; Fang et al. 2010; Zou and Zhou 2013a) and in many CMIP5 models (Fig. 3 in Song and Zhou 2014b). The biases of simulated SST are comparable or slightly larger than those in other regional air-sea coupled models with focus on East Asian monsoon domain (i.e., Li and Zhou 2010; Cha et al. 2016), although our model domain is larger than theirs. It is worth to noting that the biases of simulated SST over the Asian monsoon region in FROALS are much weaker than those in the CMIP5 multi-model ensemble mean (MMEM), implying the usefulness of the regional coupling.

Rainfall is a rigorous test of climate model performance. Figure 3 shows the spatial distribution of the JJA mean rainfall averaged from 1989 to 2010 . In observation, the monsoon rainfall affected by the orography is firstly concentrated over the Western Ghats, the foothills of the Himalayas, the Burmese coast, and the Philippines. The other three major rainbands are located over the eastern tropical Indian Ocean, east of the Philippines, and the Meiyu front region. The orography-induced rainfall is well reproduced in FROALS but with larger magnitude. The PCC is 0.66 between the observation and FROALS simulation. The simulated rainfall is underestimated east of the Philippines, and over the Indian sub-continent and the Meiyu front region (Fig. 3c). The magnitudes of the biases of simulated summer rainfall by FROALS are smaller than some regional atmospheric models that were applied to CORDEX East Asia domain (Huang et al. 2015), especially over East China and western North Pacific. Dry biases over the Indian subcontinent and the Meiyu front region are also found in CMIP5 MMEM (Sperber et al. 2013; Song and Zhou 2014b).

The observed and simulated JJA mean winds at $850 \mathrm{hPa}$ and the associated wind speeds are shown in Fig. 4. The 
observed low-level monsoon flow is well captured by FROALS, including the low level westerly associated with the Indian summer monsoon and the anticyclonic circulation over the WNP. The PCC of wind speed is 0.81 between the observation and FROALS simulation. The simulated low-level anticyclone over the WNP is stronger and shifted slightly westward compared to observations (Fig. 4c), which contribute to the dry biases east of the Philippines and over the Meiyu front region.

\section{Annual cycle}

\subsection{Latitude-time evolution of the Indian monsoon and East Asian monsoon}

Figure 5 shows the latitude-time diagram of monthly rainfall averaged between $70^{\circ} \mathrm{E}$ and $90^{\circ} \mathrm{E}$ from the observation and FROALS simulation. The observation is characterized by the seasonal evolution of Indian monsoon rainfall and the oceanic rainfall band located near $5^{\circ} \mathrm{S}$ (Fig. 5a). The development of the observed Indian summer monsoon is well reproduced in the FROALS simulation, but the simulated rainband with a larger magnitude does not propagate as far north as observation, contributing to the dry biases over the northern Indian subcontinent (Fig. 3b). Another deficiency is that FROALS fails to capture the northward propagation of the rainfall minimum south of $10^{\circ} \mathrm{N}$ during the boreal summer, which is also found in CMIP5 MMEM (Sperber et al. 2013). The PCC of rainfall over the region $10^{\circ} \mathrm{S}-30^{\circ} \mathrm{N}$ for May-October is 0.43 between the observation and FROALS simulation.

For the East Asian monsoon, the latitude-time diagrams of monthly observed and simulated rainfall averaged between $105^{\circ} \mathrm{E}$ and $140^{\circ} \mathrm{E}$ are shown in Fig. 6 . The observation is featured with a northern rainband and a southern rainband. The northern rainband begins in May, and exhibits northward propagation reaching $40^{\circ} \mathrm{N}$ in July. The southern branch begins in June with a peak in August, and is located near $15^{\circ} \mathrm{N}$. These two rainbands are well reproduced in the FROALS simulation, but with weaker magnitude of the northern branch and a 1-month delayed peak of the southern branch. The PCC of rainfall over $10^{\circ} \mathrm{N}-40^{\circ} \mathrm{N}$ for May-October is 0.77 between the observation and FROALS simulation.

\subsection{Monsoon onset, peak, withdrawal and duration}

Detailed evaluation of the annual cycle of the Asian monsoon in FROALS simulation is analyzed in this subsection by using pentad rainfall data in terms of four metrics, i.e., monsoon onset, peak, withdrawal and duration. The definitions of the four metrics follow the methodology of Wang and Lin (2002). First, the pentad time series of precipitation are smoothed with a five pentad running mean, and then the January mean rainfall is subtracted from each pentad to obtain a
Fig. 8 Same as Fig. 7, but for monsoon withdrawal pentad (left panel) and monsoon duration pentad (right panel) (a) GPCP

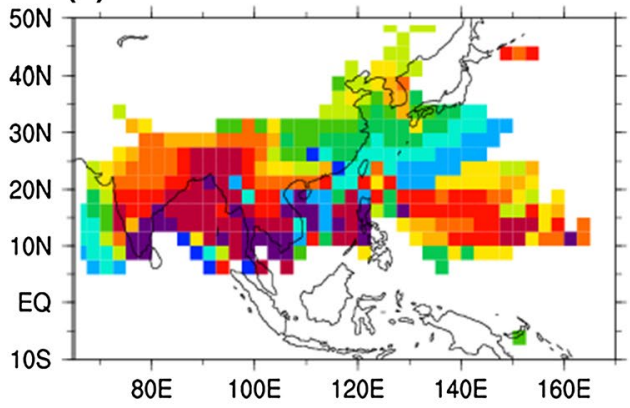

(b) FROALS

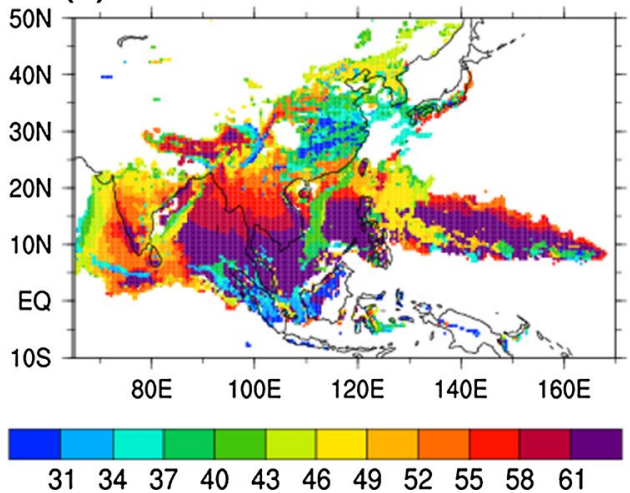

(c) GPCP

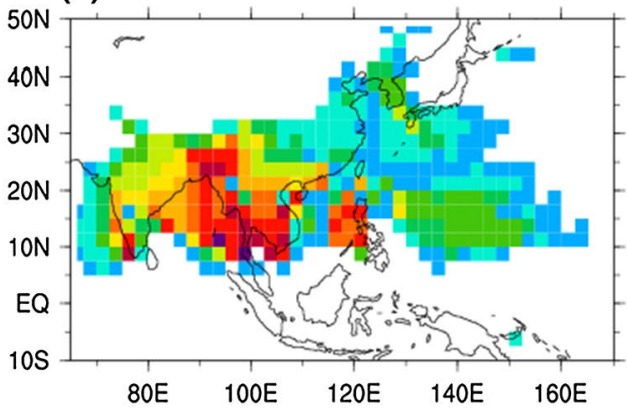

(d) FROALS

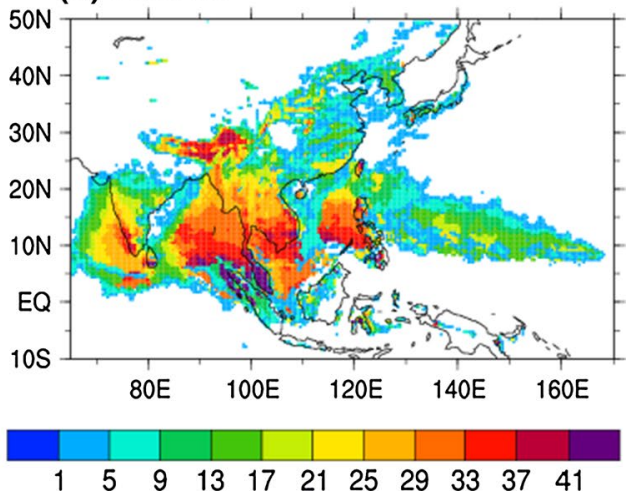


relative rainfall rate series. Monsoon onset is defined as the first pentad at which the relative rainfall rate exceeds $5 \mathrm{~mm}$ per day during May-September. The time of the monsoon peak is defined as the pentad when the maximum relative rainfall rate occurs. The withdrawal of monsoon is defined as the first pentad at which the relative rainfall rate is again $<5 \mathrm{~mm}$ per day. The monsoon duration is defined as the difference between the pentads of the monsoon withdrawal and monsoon onset. Wang and Lin (2002) discussed the cases of the regions with double rainy seasons. This method captures the major rainy season. For southern China, the spring rain represents the major rainy season during the course of the year (Wang and Lin 2002). These metrics are a stringent test for climate models (Sperber et al. 2013; Zou and Zhou 2015).

Figure 7 shows the pentads of the onset and peak of the Asian monsoon derived from the observation and FROALS simulation. The observed monsoon onset firstly occurs over Southeast Asia, and then over the South China Sea and to the southwest of India. Later, the monsoon is established over the Indian subcontinent and Meiyu front region. The final established monsoon is the western North Pacific summer monsoon. The observed progression of monsoon onset is captured in the FROALS simulation, with a PCC of 0.55 , but the simulated onset tends to occur later than observed over regions extending eastward from the Bay of Bengal to the western North Pacific. The model fails to define the monsoon over northern India and east of mainland China due to the dry biases over these two regions (Fig. 3a). These biases are also found in CMIP5 MMEM (Sperber et al. 2013). In addition, the monsoon over the South China Sea and Bay of Bengal extends too far southward in FROALS, which is not found in CMIP5 MMEM, but exists in some global climate system models (Sperber et al. 2013; Zou and Zhou 2015). However, the too far eastward extension of the western North Pacific monsoon and the delayed monsoon onset over the Arabian Sea and India, which are common biases in CMIP5 models (Sperber et al. 2013), are not evident in the FROALS simulation primarily due to the prescribed observed lateral boundary.

For the timing of the monsoon peak, the observed monsoon first reaches its peak over the southwest of India, and then over the region extending eastward from South China to south of Japan. Later, the peak of the monsoon occurs over the Indian subcontinent and North China. The peak is finally established over the western North Pacific and Southeast Asia. This progression is well reproduced in FROALS, with a PCC of 0.57 . However, the simulated monsoon peak over the Bay of Bengal occurs earlier than the observed, whereas the timing of the monsoon peak is too late over the northern South China Sea and western North Pacific, which also occurs in CMIP5 MMEM (Sperber et al. 2013).

The withdrawal of the monsoon first occurs over the West Pacific to the southeast of Japan, and then over the
East China and Arabian Sea (Fig. 8). The following monsoon withdrawal is found over India and the western North Pacific, with the latest withdrawal occurring over the region extending eastward from the Bay of Bengal to the northern South China Sea. These gross features are well captured by FROALS (Fig. 8), with a PCC of 0.42 . However, the withdrawal of the simulated monsoon occurs later than observed over the Arabian Sea, the northern South China Sea, and the western North Pacific, which is also evident in CMIP5 MMEM (Sperber et al. 2013).

The simulated and observed duration of the Asian monsoon are presented in Fig. 8. The monsoon duration is longest over the Bay of Bengal, Southeast Asia and west of the Philippines, with the second longest over India, whereas the monsoon season is relatively short over East Asia and the western North Pacific. The simulated monsoon duration matches the observed well, with a PCC of 0.59 , though the simulated duration is slightly longer than the observed counterpart over the Arabian Sea. Note that the too long monsoon duration over India and western North Pacific in CMIP5 MMEM is not seen in FROALS.

(a) OISST

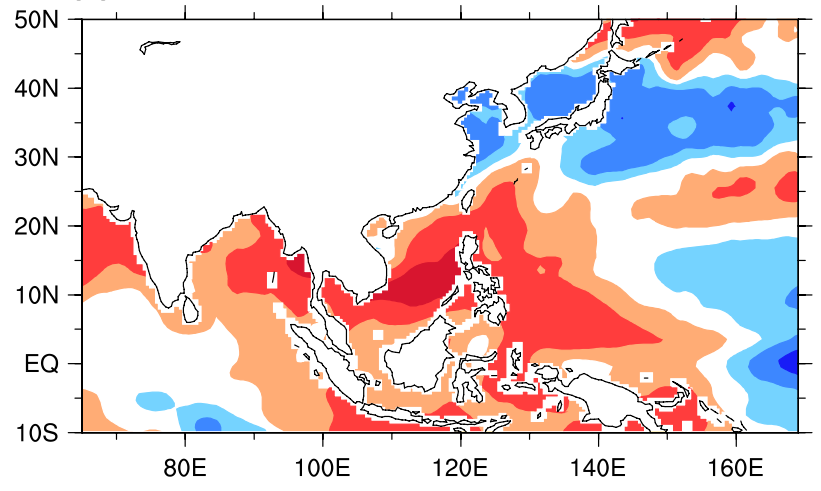

(b) FROALS

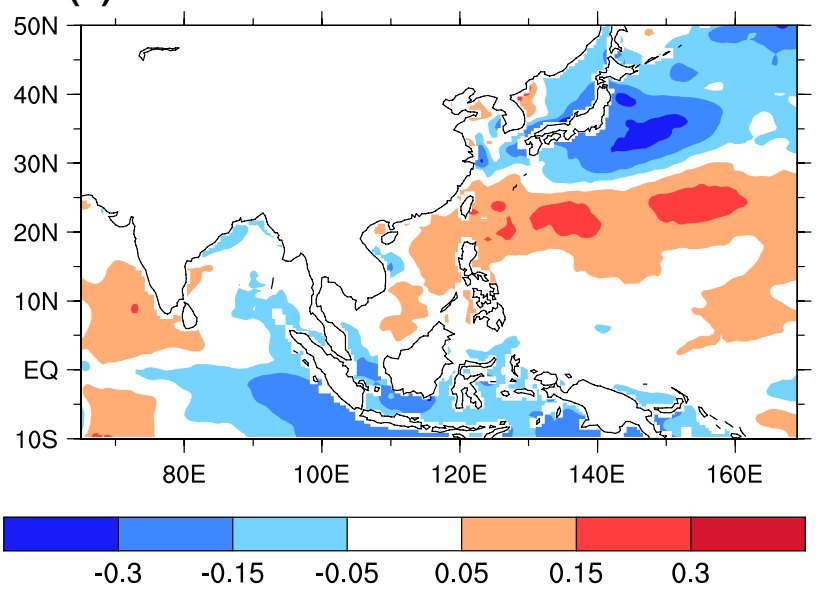

Fig. 9 a Observed and b simulated correlation coefficients between JJA mean SST and precipitation anomalies 


\section{Interannual variability}

The SST-rainfall relationship at an interannual timescale is a good metric to assess the performance of climate models (Trenberth and Shea 2005; Wu and Kirtman 2007). Figure 9 shows the observed and simulated anomalous rainfall-SST relationship over the Asian monsoon region for JJA of 1989-2010. The local SST and rainfall anomalies are positively correlated over the Maritime continent, indicating that the atmosphere is partly forced by the underlying SST anomalies. However, the correlations are negative over the eastern Bay of Bengal, the northern South China Sea, the WNP and the Meiyu front region. These negative correlations imply that the SST anomalies are primarily affected by the overlying atmosphere (Wang et al. 2005; Wu and Kirtman 2007).

Previous studies found that the negative SST-rainfall relationship over the Asian monsoon in boreal summer is not well captured by the SST-forced AGCM experiments, which is the main factor leading to the low skill of the simulated rainfall (Wang et al. 2004a; Wang et al. 2005; Kumar et al. 2005; Zhou et al. 2009b). The positive SST-rainfall relationship over the Maritime continent is well captured by FROALS, along with the negative correlations extending northwesterly from the eastern Bay of Bengal to the south of Japan. The PCC of the correlations is 0.53 between the simulation and observation. However, the deficiency is the model fails to reproduce the negative SST-rainfall relationship to the east of the Philippines.
The East Asian summer monsoon (EASM) is an important component of the Asian summer monsoon, and is composed of both tropical and subtropical systems (Zhou et al. 2009c). A simple EASM index (Wang et al. 2008), which is defined as the difference between the $850 \mathrm{hPa}$ JJA mean zonal wind averaged over $\left(22.5^{\circ}-32.5^{\circ} \mathrm{N}, 110^{\circ}-140^{\circ} \mathrm{E}\right)$ and $\left(5^{\circ}-15^{\circ} \mathrm{N}, 90^{\circ}-130^{\circ} \mathrm{E}\right)$, has been widely used to validate the CMIP5 and CMIP3 models (Sperber et al. 2013; Song and Zhou 2014a, b). We calculate the temporal correlation coefficient between the FROALS-simulated and observed EASM index, but the skill is very low (0.05). Although the skill is also low in some CMIP5 AMIP simulations (Song and Zhou 2014a), it should be acknowledged that our model skill is lower than that of CMIP5 AMIP MMEM in this regard.

To explore the underlying mechanisms, the JJA mean rainfall and $850 \mathrm{hPa}$ wind anomalies are regressed upon the standardized EASM index derived from the simulation and the observation (Fig. 10), respectively. In observations, followed by a strong EASM with positive rainfall anomalies over the Meiyu front region, an anomalous anticyclone is pronounced over the WNP. The anomalous anticyclone is the Rossby wave response to the reduced rainfall over the WNP. The reduction of rainfall over WNP could be ascribed to at least three factors (Xie et al. 2009; Wu et al. 2009, 2010; Song and Zhou 2014a, b). The first is the cold SSTA over the West Pacific east of $150^{\circ} \mathrm{E}$, which leads to local negative rainfall anomalies. The second is the warm SSTA over the Maritime continent, which reduces
Fig. 10 Spatial distributions of rainfall (shaded; $\mathrm{mm} / \mathrm{day})$ and $850 \mathrm{hPa}$ wind (vector; $\mathrm{m} / \mathrm{s}$ ) in JJA regressed on the standardized EASM index during 1989-2010 in the a observation and $\mathbf{b}$ FROALS. The EASM index is defined as the difference between the $850 \mathrm{hPa}$ JJA mean zonal wind averaged over $\left(22.5^{\circ}-32.5^{\circ} \mathrm{N}, 110^{\circ}-140^{\circ} \mathrm{E}\right)$ and $\left(5^{\circ}-15^{\circ} \mathrm{N}, 90^{\circ}-130^{\circ} \mathrm{E}\right)$. The SST (shaded; K) regressed on the standardized EASM index derived from $\mathbf{c}$ observation and d FROALS is shown in the right panel
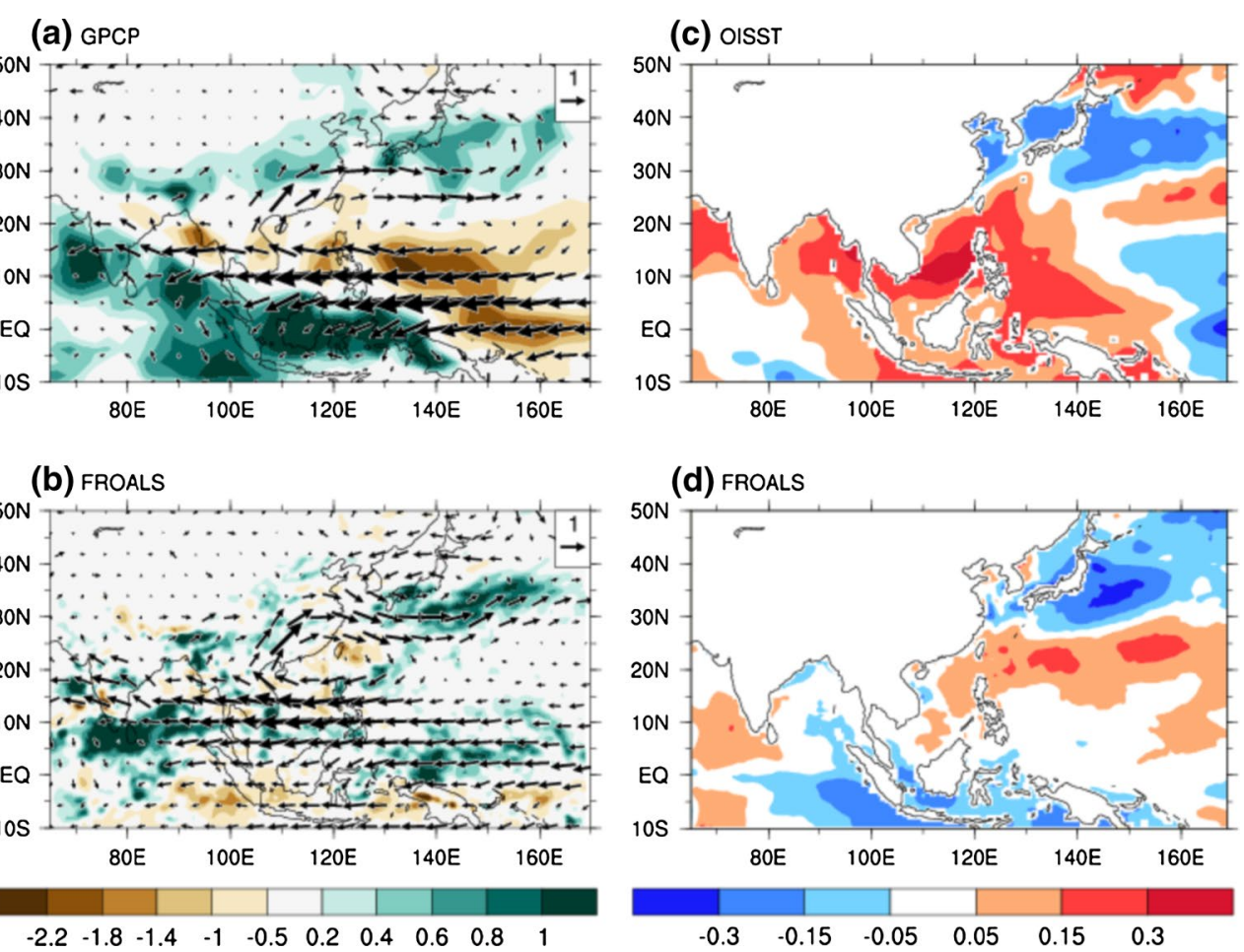

(d) FROALS

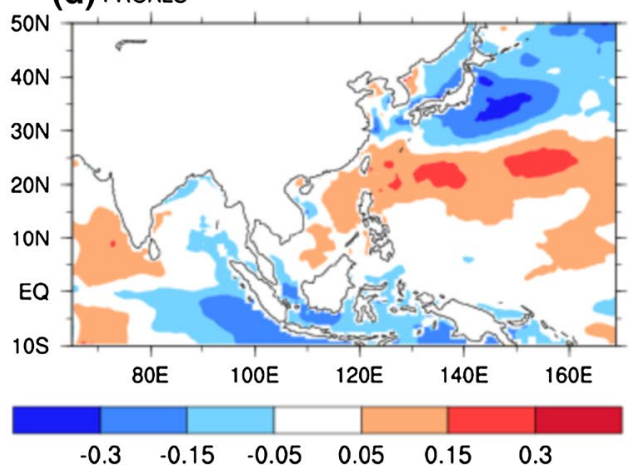


the rainfall over the WNP through anomalous local Hadley circulation. The third is the warm SSTA over the eastern Tropical Indian Ocean, which induces Ekman divergence over the WNP through the low-level Kelvin wave response (Xie et al. 2009; Wu et al. 2009). Note that the anomalous anticyclone over WNP favors local warm SSTAs (Fig. 10c) through the enhancement of downward shortwave radiative fluxes. Thus, the negative rainfall anomalies and the warm SSTAs together result in the negative SST-rainfall relationship over the WNP shown in Fig. 9.

The corresponding anomalous anticyclone is, to some extent, captured by FROALS, along with the positive rainfall anomalies over the Meiyu front region, in particular over southern Japan and to its east. However, the strength of the simulated anomalous anticyclone is much weaker than the observed counterpart. This may be due to the incorrect simulated SSTA, i.e., warm SSTA over the West Pacific east of $150^{\circ} \mathrm{E}$, cold SSTA over the Maritime continent and the tropical eastern Indian Ocean. This explains the poorly simulated interannual variability of the EASM and the incorrect SST-rainfall relationship over the WNP. We will attempt to further improve the model's performance in simulating the inter-annual variability of East Asian monsoon by calibrating the key physical parameters, as that did in Yang et al. (2015).

\section{Boreal summer intraseasonal variability and extreme climate indices}

In this section, boreal summer intraseasonal variability of the Asian monsoon and extreme climate indices are evaluated in comparison to the results derived from GPCP daily rainfall during 1998-2010. The 20-100 day bandpass filtered variances of rainfall from the observation and FROALS are shown in Fig. 11. In observation, the regions with high climatological rainfall are generally accompanied with strong intraseasonal variability, i.e., the Western Ghats, Bay of Bengal, tropical eastern Indian Ocean, and northern South China Sea. The exception is found over the WNP, where the variance maxima of intraseasonal variability shift northward approximately 5 degrees in comparison with the corresponding climatological rainfall maxima. These characteristics are well reproduced in FROALS, although with larger amplitude. The PCC is 0.60 between the simulation and observation. This spatial pattern derived from FROALS is, to some extent, better than that derived from CMIP5 MMEM, especially in terms of the strong intraseasonal variability over the Western Ghats.

Extreme climate indices are usually used to evaluate the performance of high resolution regional climate models (Bell et al. 2004; Gao et al. 2002; Zou and Zhou 2013b), because the physical processes and the atmospheric dynamics responsible for extreme climate events are better resolved in climate models with higher resolution (Bell et al. 2004; Kitoh et al. 2009). Figure 12 shows the probability density function (PDF) distribution of daily rainfall rates derived from the observation and FROALS over eight selected regions during JJA from 1998 to 2010. The shapes of PDF distributions of observed daily rain rate are well captured in FROALS. However, the model tends to underestimate the frequencies of rain rates between 9 and $30 \mathrm{~mm} /$ day and overestimate the frequencies of rain rates $>42 \mathrm{~mm} /$ day.

Two extreme climate indices are employed in this study. One is R5d, which is defined as the maximum consecutive 5-day total precipitation. The other is consecutive dry days (CDD), which is an index defined as the greatest number of consecutive days with daily precipitation below $1 \mathrm{~mm}$. The spatial distributions of JJA R5d and CDD averaged from 1998 to 2010 derived from observation and FROALS

(a) GPCP

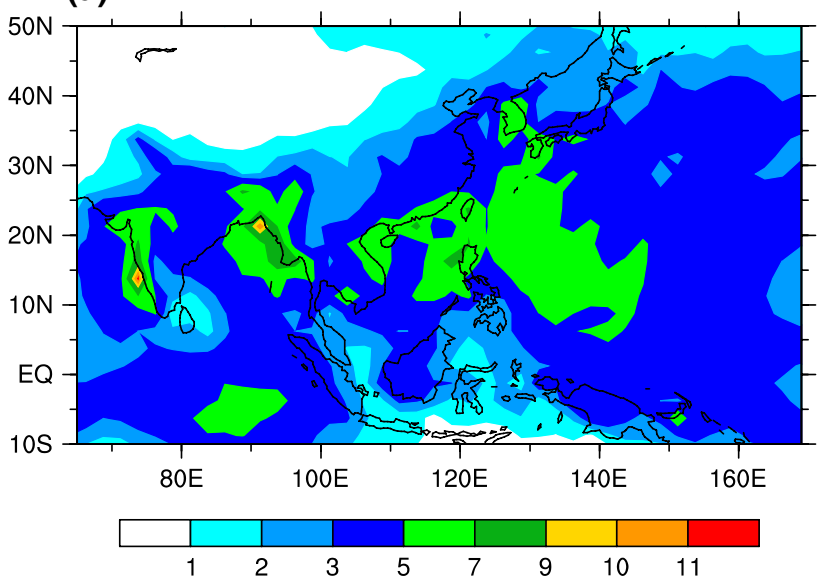

(b) FROALS

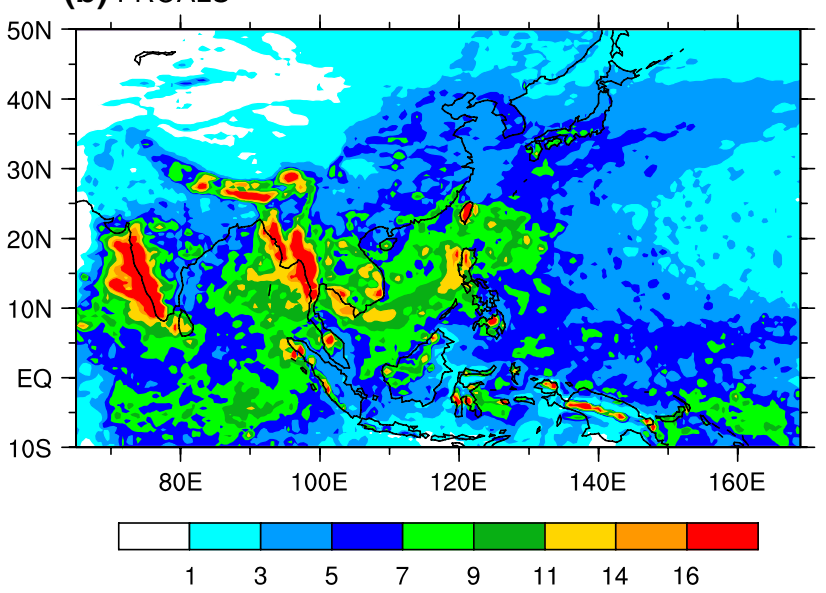

Fig. 11 20-100 day bandpass filtered rainfall variance for JJA during 1998-2010 from a observation and b FROALS 
(a) TIO

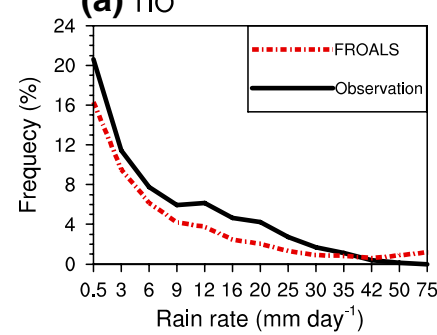

(e) SC

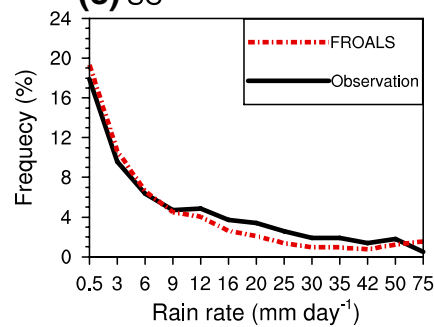

(b) sscs

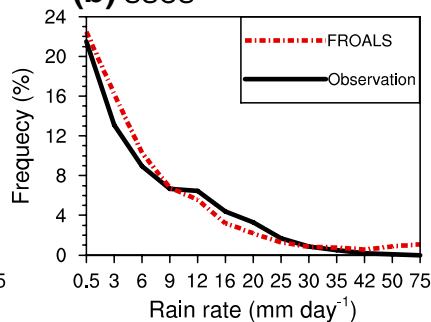

(f) YR

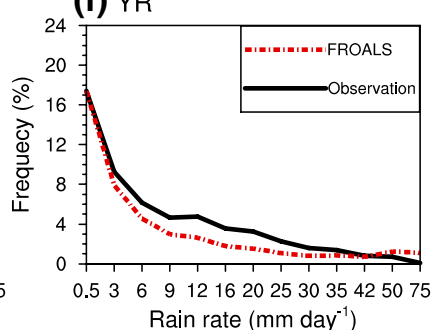

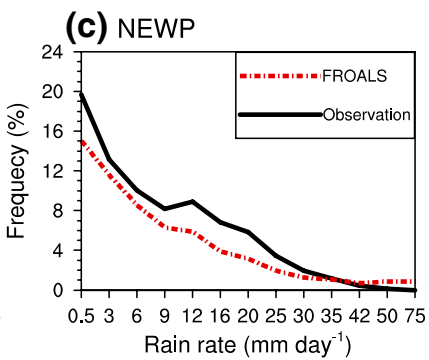

(g) WNP

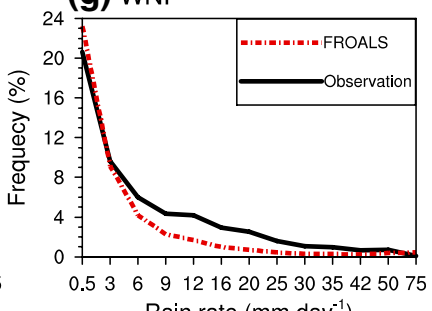

Rain rate $\left(\mathrm{mm}\right.$ day $\left.^{-1}\right)$

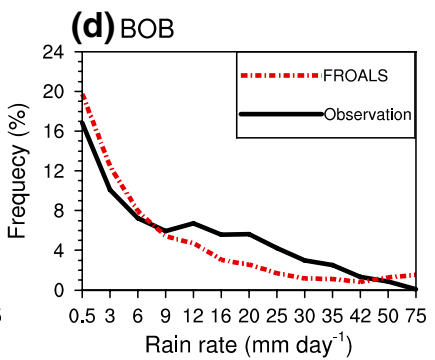

(h) India

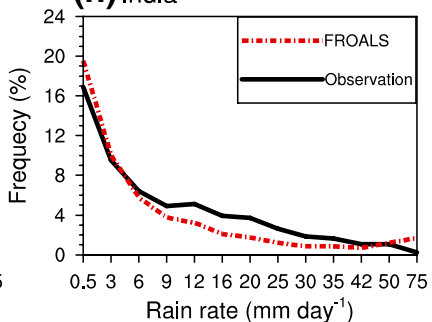

Fig. 12 Probability density function (PDF, \%) distributions of daily rain rate over different regions derived from observation and FROALS for June-August during 1998-2010. The eight subregions of the simulated domain are selected: Tropical Indian Ocean (TIO; $-10^{\circ} \mathrm{S}-$ $\left.0^{\circ}, 70^{\circ} \mathrm{E}-100^{\circ} \mathrm{E}\right)$; Southern South China Sea (SSCS; $-5^{\circ} \mathrm{S}-10^{\circ} \mathrm{N}$,

$\left.105^{\circ} \mathrm{E}-120^{\circ} \mathrm{E}\right)$; northern equatorial western Pacific (NEWP; $0^{\circ}-10^{\circ} \mathrm{N}$, $\left.130^{\circ} \mathrm{E}-165^{\circ} \mathrm{E}\right)$; Bay of Bengal $\left(\mathrm{BOB} ; 10^{\circ} \mathrm{N}-20^{\circ} \mathrm{N}, 80^{\circ} \mathrm{E}-95^{\circ} \mathrm{E}\right)$; South China $\left(\mathrm{SC} ; 16^{\circ} \mathrm{N}-26^{\circ} \mathrm{N}, 105^{\circ} \mathrm{E}-125^{\circ} \mathrm{E}\right.$ ); Yangtze River (YR; $26^{\circ} \mathrm{N}-33^{\circ} \mathrm{N}, 105^{\circ} \mathrm{E}-125^{\circ} \mathrm{E}$ ); Western North Pacific (WNP; $13^{\circ} \mathrm{N}-25^{\circ} \mathrm{N}$, $\left.125^{\circ} \mathrm{E}-160^{\circ} \mathrm{E}\right)$; and India $\left(8^{\circ} \mathrm{N}-32^{\circ} \mathrm{N}, 70^{\circ} \mathrm{E}-90^{\circ} \mathrm{E}\right)$

Fig. 13 Spatial distributions of JJA maximum consecutive 5-day total precipitation (left panel, $\mathrm{mm}$ ) and consecutive dry days (right panel) averaged from 1998 to 2010 derived from $\mathbf{a}, \mathbf{c}$ observation and $\mathbf{b}, \mathbf{d}$ FROALS

\section{(a) GPCP}

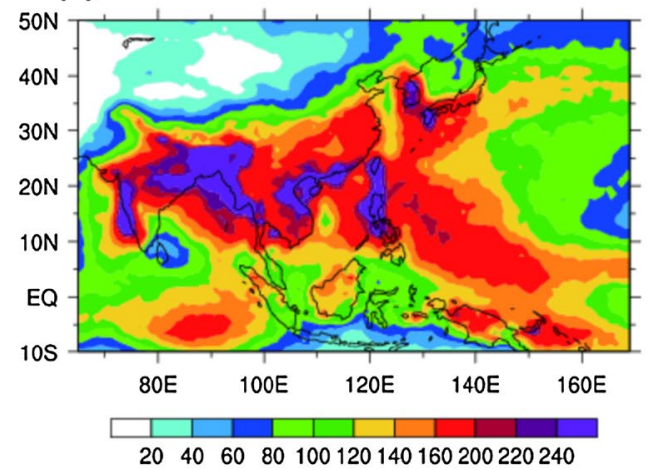

(b) FROALS

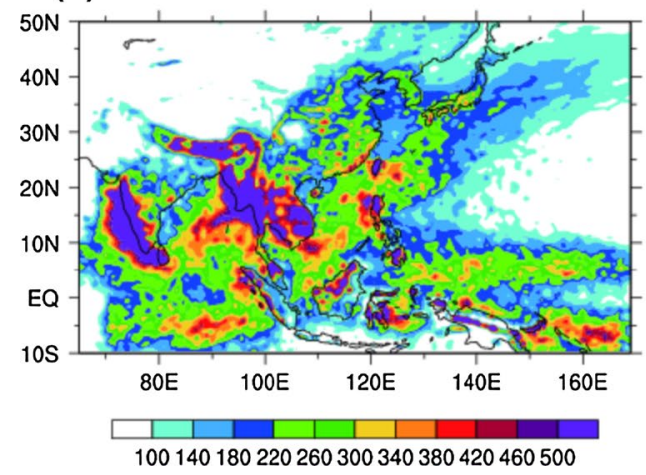

(c) GPCP

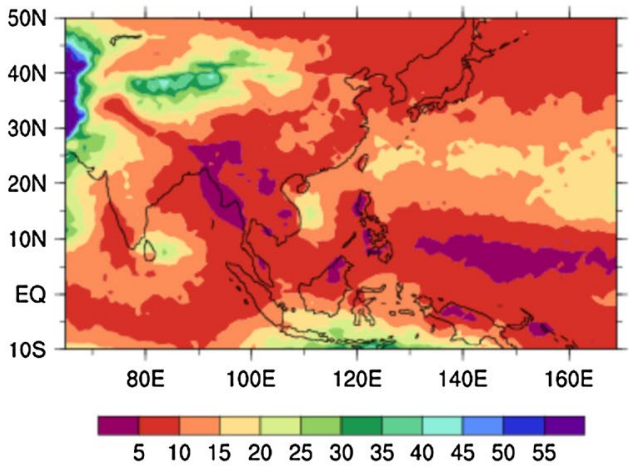

(d) FROALS

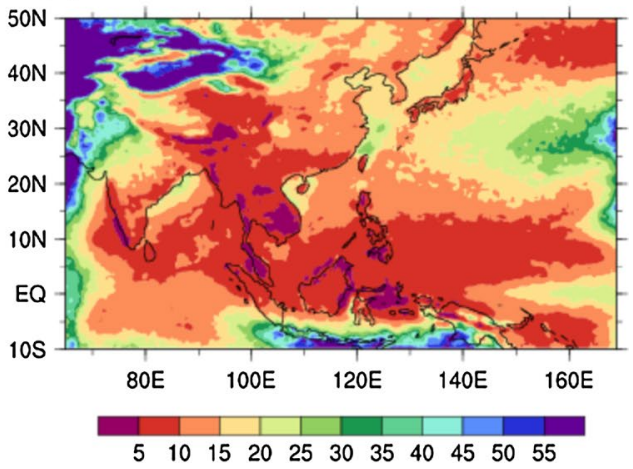

are shown in Fig. 13. R5d has a similar spatial pattern as JJA mean rainfall (Fig. 3) in both observation and simulation. FROALS tends to overestimate R5D over most of the simulated domain due to the overestimated frequencies of rain rates higher than $42 \mathrm{~mm} /$ day, as shown in Fig. 12. The PCC of R5d is 0.63 between observations and simulation. 
The maxima of the observed CDD are found over central Asia and northwestern China, whereas lower CDD are observed in regions where the major rainbands are observed. These features are well captured in FROALS, though a larger magnitude of CDD is found over the northwestern simulated domain. The PCC is 0.70 between observations and simulation.

\section{Summary}

In this study, a previously developed regional oceanatmosphere coupled model FROALS was applied to the CORDEX East Asia domain in replacement of the customized regional atmospheric model. The performance of FROALS in the simulation of the Asian summer monsoon was assessed by using the metrics developed by the CLIVAR Asian-Australian Monsoon Panel (AAMP) Diagnostics Task Team. The strengths and weaknesses of FROALS were documented along with a comparison to the skill of the CMIP5 global models.

FROALS exhibits reasonable performance in simulating the climatology of the Asian summer monsoon during 1989-2010, including the low-level monsoon flow and the orography-induced rainfall. The simulated JJA mean SST biases are weaker than those in the CMIP5 multi-model ensemble mean (MMEM). The simulated western North Pacific subtropical high is slightly stronger and shifted westward compared to observations, which contributes to the dry biases east of the Philippines and over the Meiyu front region.

The seasonal evolution of monsoon rainfall over India and East Asia are well captured in FROALS, along with the four metrics related to the annual monsoon cycle. In particular, for monsoon duration, the simulated features match the observed counterpart well (with a PCC of 0.59). Overall, the skill of FROALS approaches that of CMIP5 MMEM in simulating the annual cycle of the Asian summer monsoon, although some biases in CMIP5 MMEM are also found in FROALS, i.e., lack of the extension of the monsoon over east of the China mainland, earlier (later) monsoon peak over the Bay of Bengal (northern South China Sea and western North Pacific). The similar biases between FROALS and CMIP5 MMEM highlight the importance of improved representation of local forcing and model physics inside the Asian monsoon domain.

Corresponding to a strong East Asian summer monsoon, an anomalous anticyclone is evident over the WNP in both observations and simulation. However, the simulated strength is weaker than the observed, probably due to the incorrect simulated SSTA over key regions, i.e., the West Pacific east of $150^{\circ} \mathrm{E}$, the Maritime continent and the tropical eastern Indian Ocean.
The spatial pattern of the intraseasonal variability variance of the Asian summer monsoon is well reproduced in FROALS with larger amplitude. Two indices are selected, including the maximum consecutive 5-day total precipitation (R5d) and consecutive dry days (CDD), to validate the model performance in simulating extreme climate conditions. The results indicate that the observed spatial pattern is well captured in FROALS, especially for CDD. However, the model tends to overestimate the maximum consecutive 5-day total precipitation due to the higher frequencies of rainfall rates $>42 \mathrm{~mm} /$ day.

Finally, the overall reasonable performance of FROALS in simulating the Asian summer monsoon at various timescales suggests that this model could be used as a dynamical downscaling tool nested within the global climate model with coarse resolution to develop high-resolution regional climate change projections over the CORDEX East Asia domain. These results will be presented in a separate paper.

Acknowledgments This work was jointly supported by National Key Basic Research Program of China (2013CB956204), National Natural Science Foundation of China (41575105, 41330423). FROALS model source code and the simulation results were stored on a local cluster at LASG/IAP and are available upon request (zoulw@ mail.iap.ac.cn).

Open Access This article is distributed under the terms of the Creative Commons Attribution 4.0 International License (http://creativecommons.org/licenses/by/4.0/), which permits unrestricted use, distribution, and reproduction in any medium, provided you give appropriate credit to the original author(s) and the source, provide a link to the Creative Commons license, and indicate if changes were made.

\section{References}

Adler RF, Huffman GJ, Chang A, Ferraro R, Xie PP, Janowiak J, Rudolf B, Schneider U, Curtis S, Bolvin D, Gruber A, Susskind J, Arkin P, Nelkin E (2003) The version-2 global precipitation climatology project (GPCP) monthly precipitation analysis (1970-present). J Hydrometeorol 4:1147-1167

Aldrian E, Sein D, Jacob D, Gates LD, Podzun R (2005) Modelling Indonesian rainfall with a coupled regional model. Clim Dyn 25:1-17

Antonov JI, Locarnini RA, Boyer TP, Mishonov AV, Garcia HE (2006) World Ocean Atlas 2005, vol 2: salinity. In: Levitus S (ed) NOAA Atlas NESDIS 62. U.S. Government Printing Office, Washington

Bao Q, Lin P, Zhou T, Liu Y, Yu Y, Wu G, He B, He J, Li L, Li J, Li Y, Liu H, Qiao F, Song Z, Wang B, Wang J, Wang P, Wang X, Wang Z, Wu B, Wu T, Xu Y, Yu H, Zhao W, Zheng W, Zhou L (2013) The flexible global ocean-atmosphere-land system model, spectral version 2: FGOALS-s2. Adv Atmos Sci 30:561-576

Bell J, Sloan L, Snyder M (2004) Changes in extreme climate events: a future climate scenario. J Clim 17:81-87

Canuto VM, Howard A, Cheng Y, Dubovikov MS (2001) Ocean turbulence. Part I: one-point closure model-momentum and heat vertical diffusivities. J Phys Oceanogr 31:1413-1426 
Canuto VM, Howard A, Cheng Y, Dubovikov MS (2002) Ocean turbulence. Part II: vertical diffusivities of momentum, heat, salt, mass, and passive scalars. J Phys Oceanogr 32:240-264

Cha D-H, Jin CS, Moon JH, Lee DK (2016) Improvement of regional climate simulation of East Asian summer monsoon by coupled air-sea interaction and large-scale nudging. Int $\mathrm{J}$ Climatol 36:334-345. doi:10.1002/joc.4349

Chen J, Bordoni S (2014) Intermodel spread of East Asian summer monsoon simulations in CMIP5. Geophys Res Lett 41:1314-1321

Christensen JH, Hewitson B, Busuioc A, Chen A, Gao X, Held R, Jones R, Kolli RK, Kwon WK, Laprise R, Magana Rueda V, Mearns L, Menendez CG, Räisänen J, Rinke A, Sarr A, Whetton P, Arritt R, Benestad R, Beniston M, Bromwich D, Caya D, Comiso J, de Elia R, Dethloff K (2007) Regional climate projections. In: Solomon S et al (eds) Climate change 2007: the physical science basis. Cambridge University Press, Cambridge, pp 847-940

Dickinson RE, Henderson-Sellers A, Kennedy PJ (1993) Biosphereatmosphere transfer scheme (BATS) version 1e as coupled to the NCAR community climate model. NCAR technical note, NCAR/TN-387 + STR, 72 pp

Emanuel KA (1991) A scheme for representing cumulus convection in large-scale models. J Atmos Sci 48:2313-2335

Emanuel KA, Rothman MZ (1999) Development and evaluation of a convection scheme for use in climate models. J Atmos Sci 56:1766-1782

Fang Y, Zhang Y, Tang J, Ren X (2010) A regional air-sea coupled model and its application over East Asia in the summer of 2000. Adv Atmos Sci 27:583-593

Gao X, Zhao Z, Giorgi F (2002) Changes of extreme events in regional climate simulations over East Asia. Adv Atmos Sci 19:927-942

Gent P, Mcwilliams JC (1990) Isopycnal mixing in ocean circulation models. J Phys Oceanogr 20:150-155

Giorgi F, Mearns LO (1999) Introduction to special section: regional climate modeling revisited. J Geophys Res 104:6335-6352

Giorgi F, Jones C, Asrar GR (2009) Addressing climate information needs at the regional level: the CORDEX framework. WMO Bull $58: 175-183$

Holtslag AAM, de Bruijn EIF, Pan H-L (1990) A high resolution air mass transformation model for short-range weather forecasting. Mon Weather Rev 118:1561-1575

Huang DQ, Zhu J, Zhang YC, Huang AN (2013) Uncertainties on the simulated summer precipitation over Eastern China from the CMIP5 models. J Geophys Res Atmos 118:9035-9047

Huang B, Polanski S, Cubasch U (2015) Assessment of precipitation climatology in an ensemble of CORDEX-East Asia regional climate simulations. Clim Res 64:141-158

Jones C, Giorgi F, Asrar G (2011) The coordinated regional downscaling experiment: CORDEX an international downscaling link to CMIP. CLIVAR Exch 16(2):34-40

Kanamitsu M, Ebisuzaki W, Woollen J, Yang S-K, Hnilo JJ, Fiorino M, Potter GL (2002) NCEP-DOE AMIP-II reanalysis (R-2). Bull Am Meteorol Soc 83(11):1631-1643

Kiehl JT, Hack JJ, Bonan GB, Boville BA, Breigleb BP, Williamson DL, Rasch PJ (1996) Description of the NCAR community climate model (CCM3). Technical report, NCAR/TN-420 + STR, National Center for Atmospheric Research

Kitoh A, Kusunoki S (2008) East Asian summer monsoon simulated by a 20-km mesh AGCM. Clim Dyn 31:389-401

Kitoh A, Ose T, Kurihara K, Kusunoki S, Sugi M, KAKUSHIM Team-3 Modeling Group (2009) Projection of changes in future weather extremes using super-high-resolution global and regional atmospheric models in the KAKUSHIN program: results of preliminary experiments. Hydrol Res Lett 3:49-53
Kumar KK, Hoerling M, Rajagopalan B (2005) Advancing dynamical prediction of Indian monsoon rainfall. Geophys Res Lett 32:L08704. doi:10.1029/2004GL021979

Kusunoki S, Yoshimura J, Yoshimimura H, Noda A, Oouchi K, Mizuta $\mathrm{R}$ (2006) Change of Baiu rainband in global warming projection by an atmospheric general circulation model with a $20-\mathrm{km}$ grid size. J Meteorol Soc Jpn 84:581-611

Leung LR, Mearns LO, Giorgi F, Wilby RL (2003) Regional climate research-needs and opportunities. Bull Am Meteorol Soc 84:89-95

Li T, Zhou G (2010) Preliminary results of a regional air-sea coupled model over East Asia. Chin Sci Bull. doi:10.1007/ s11434-010-0071-0

Li H, Dai A, Zhou T, Lu J (2010) Responses of East Asian summer monsoon to historical SST and atmospheric forcing during 1950-2000. Clim Dyn 34:501-514

Li L, Lin P, Yu Y, Wang B, Zhou T, Liu L, Liu H, Liu J, Bao Q, Xu S, Huang W, Xia K, Pu Y, Dong L, Shen S, Liu Y, Hu N, Liu M, Sun W, Shi X, Zheng W, Wu B, Song M, Liu H, Zhang X, Wu G, Xue W, Huang X, Yang G, Song Z, Qiao F (2013) The flexible global ocean-atmosphere-land system model: grid-point version 2: FGOALS-g2. Adv Atmos Sci 30:543-560. doi:10.1007/ s00376-012-2140-6

Liu H, Lin P, Yu Y, Zhang X (2012) The baseline evaluation of LASG/ IAP climate system ocean model (LICOM) version 2. Acta Meteorol Sin 26:318-329

Locarnini RA, Mishonov AV, Antonov JI, Boyer TP, Garcia HE (2006) World Ocean Atlas 2005, vol 1: temperature. In: Levitus S (ed) NOAA Atlas NESDIS 61. U.S. Government Printing Office, Washington, DC

Lu SH, Chen YC, Zhu BC (2000) A coupled ocean model and atmosphere model and simulation experiment in the South China Sea area. Plateau Meteorol (in Chinese) 19:415-426

Pal JS, Small EE, Eltahir EAB (2000) Simulation of regional-scale water and energy budgets: representation of subgrid cloud and precipitation processes within RegCM. J Geophys Res 105(29):29579-29594

Pal JS et al (2007) Regional climate modeling for the developing world: the ICTP RegCM3 and RegCNET. Bull Am Meteorol Soc 88:1395-1409

Ratnam JV, Giorgi F, Kaginalkar A, Cozzini S (2009) Simulation of the Indian monsoon using the RegCM3-ROMS regional coupled model. Clim Dyn 33:119-139

Ren X, Qian Y (2005) A coupled regional air-sea model, its performance and climate drift in simulation of the East Asian summer monsoon in 1998. Int J Climatol 25:679-692

Reynolds RW, Rayner NA, Smith TM, Stokes DC, Wang W (2002) An improved in situ and satellite SST analysis for climate. J Clim 15:1609-1625

Song F, Zhou T (2014a) Interannual variability of east asian summer monsoon simulated by CMIP3 and CMIP5 AGCMs: skill dependence on Indian Ocean-Western Pacific anticyclone teleconnection. J Clim 27:1679-1697

Song F, Zhou T (2014b) The climatology and interannual variability of East Asian summer monsoon in CMIP5 coupled models: does air-sea coupling improve the simulations? J Clim 27:8761-8777

Sperber KR, Annamalai H, Kang IS, Kioth A, Moise A, Turner A, Wang B, Zhou T (2013) The Asian summer monsoon: an intercomparison of CMIP5 vs. CMIP3 simulations of the late 20th century. Clim Dyn 41:2711-2744

Trenberth KE, Shea DJ (2005) Relationships between precipitation and surface temperature. Geophys Res Lett 32:L14703. doi:10. 1029/2005GL022760

Turner A, Sperber KR, Slingo J, Meehl G, Mechoso CR, Kimoto M, Giannini A (2011) Modeling monsoon: understanding and predicting current and future behavior. In: C-P Chang et al (eds) The 
global monsoon system: research and forecast, 2nd edn. World Scientific, Singapore, pp 421-454

Valcke S (ed) (2006) OASIS3 user guide (prism_2-5). PRISM Support Initiative Report No. 3, CERFACS, Toulouse, France

Wang B, Lin H (2002) Rainy season of the Asian-Pacific summer monsoon. J Clim 15:386-398

Wang B, Kang IS, Lee JY (2004a) Ensemble simulations of Asian-Australian monsoon variability by 11 AGCMs. J Clim 17:803-818

Wang Y, Leung LR, McGregor JL, Lee DK, Wang WC, Ding Y, Kimura F (2004b) Regional climate modeling: progress, challenges, and prospects. J Meteorol Soc Jpn 82:1599-1628

Wang B, Ding Q, Fu X, Kang IS, Jin K, Shukla J, Doblas-Reyes F (2005) Fundamental challenge in simulation and prediction of summer monsoon rainfall. Geophys Res Lett 32:L15711. doi:10. 1029/2005GL022734

Wang B, Wu Z, Li J, Liu J, Chang C-P, Ding Y, Wu G-X (2008) How to measure the strength of the East Asian summer monsoon? J Clim 21:4449-4463

Wu R, Kirtman BP (2007) Regimes of seasonal air-sea interaction and implications for performance of forced simulations. Clim Dyn 29:393-410

Wu B, Zhou T, Li T (2009) Seasonally evolving dominant interannual variability modes of East Asian climate. J Clim 22:2992-3005

Wu B, Li T, Zhou T (2010) Relative contributions of the Indian Ocean and local SST anomalies to the maintenance of the western North Pacific anomalous anticyclone during El Nino decaying summer. J Clim 23:2974-2986

Xie SP, Miyama T, Wang Y, Xu H, de Szoeke SP, Small RJO, Richards KJ, Mochizuki T, Awaji T (2007) A regional ocean-atmosphere model for eastern Pacific climate: toward reducing tropical biases. J Clim 20:1504-1522

Xie SP, Hu K, Hafner J, Tokinage H, Du Y, Huang G, Sampe T (2009) Indian Ocean capacitor effect on Indo-western Pacific climate during the summer following El Niño. J Clim 22:730-747

Yang B, Zhang YC, Qian Y, Huang A, Yan H (2015) Calibration of a convective parameterization scheme in the WRF model and its impact on the simulation of East Asian summer monsoon precipitation. Clim Dyn 44:1661-1684

Yao S, Zhang Y (2010) Simulation of China summer precipitation using a regional air-sea coupled model. Acta Meteorol Sin 24:203-214
Zeng X, Zhao M, Dickinson RE (1998) Intercomparison of bulk aerodynamic algorithms for the computation of sea surface fluxes using TOGA COARE and TAO data. J Clim 11:2628-2644

Zhou T, Wu B, Scaife AA, Bronnimann S, Cherchi A, Fereday D, Fischer AM, Folland CK, Jin KE, Kinter J, Knight JR, Kucharski F, Kusunoki S, Lau N-C, Li L, Nath MJ, Nakaegawa T, Navarra A, Pegion P, Rozanov E, Schubert S, Sporyshev P, Voldoire A, Wen X, Yoon JH, Zeng N (2009a) The CLIVAR C20C project: which components of the Asian-Australian monsoon circulation variations are forced and reproducible? Clim Dyn 33(7):1051-1068

Zhou T, Wu B, Wang B (2009b) How well do atmospheric general circulation models capture the leading modes of the interannual variability of Asian-Australian Monsoon? J Clim 22:1159-1173

Zhou T, Gong D, Li J, Li B (2009c) Detecting and understanding the multi-decadal variability of the East Asian summer monsoonrecent progress and state of affairs. Meteorol Z 18(4):455-467

Zou L, Zhou T (2011) Sensitivity of a regional ocean-atmosphere coupled model to convection parameterization over western North Pacific. J Geophys Res 116:D18106. doi:10.1029/201 1JD015844

Zou L, Zhou T (2012) Development and evaluation of a regional ocean-atmosphere coupled model with focus on the western North Pacific summer monsoon simulation: impacts of different atmospheric components. Sci China Earth Sci 55:802-815

Zou L, Zhou T (2013a) Can a regional ocean atmosphere coupled model improve the simulation of the interannual variability of the western North Pacific summer monsoon? J Clim 26:2353-2367

Zou L, Zhou T (2013b) Near future (2016-2040) summer precipitation changes over China under RCP8. 5 emission scenario projected by a regional climate model: a comparison between RCM downscaling and driving GCM. Adv Atmos Sci 30(3):806-818

Zou L, Zhou T (2015) Asian summer monsoon onset in simulations and CMIP5 projections using four Chinese climate models. Adv Atmos Sci 32(6):794-806

Zou L, Qian Y, Zhou T, Yang B (2014) Parameter tuning and calibration of RegCM3 with MIT-Emanuel cumulus parameterization scheme over CORDEX East Asia domain. J Clim 27:7687-7701 